\section{August Bournonvilles ballet til Meyerbeers opera Robert le Diable}

Af seniorforsker, dr. phil. Knud Arne Jürgensen

"Den første hvide ballet."

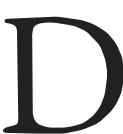
ette er den betegnelse man $\mathrm{i}$ ballethistorien almindeligvis har benyttet om den italiensk-franske koreograf Filippo Taglionis divertissement i 3. akten af den tysk-franske komponist Giacomo Meyerbeers opera Robert le Diable. Denne såkaldte grand opéra blev uropført på L’Opéra i Paris (hvis officielle navn dengang var Théâtre de l'Académie Royale de Musique) den 21. november 1831 og blev omgående en umådelig succes; inden for kun tre år nåede værket således at blive opført på i alt 77 teatre i 10 lande, herunder også Danmark, hvor Det Kongelige Teater havde première på operaen den 28 . oktober 1833, nu med titlen Robert af Normandiet.

At Meyerbeers opera ikke blot er et epokegørende værk i operahistorien, men $i$ lige så høj grad repræsenterer et vendepunkt i ballethistorien, skyldes det store balletdivertissement, som udspiller sig i operaens tredie akts finale, hvor titelhelten (Robert) i en klosterruin konfronteres med et midnatsorgie af nonner, der har brudt deres klosterløfte. Dette balletoptrin blev uhyre berømt i samtiden, og vakte enten begejstrede eller afskyvækkende reaktioner hos dem der så det, heriblandt vores egen H.C.
Andersen, der lod sig henrive af disse døde nonners natlige danse. Andersen beskriver således denne scene med ordene "yppig nøgenhed" og "et vanhelligende Stevne", mens komponisten Richard Wagner omtaler scenen i mere ligefremme og begejstrede vendinger: "[balletten i] Robert le Diable har en pragtfuld, næsten rystende stemning over sig ... det er i sandhed udødeligt". 1 Det er uomtvisteligt at denne balletscene fik en afgørende betydning for ballettens hele videre kunstneriske udvikling. Ikke alene blev Taglionis divertissement koreograferet for den nok største ballerina nogensinde, datteren Marie Taglioni (1804-1884), men balletten fremstillede desuden et helt ny og indgående billede af de ubevidste sider $\mathrm{i}$ menneskets sind, og hvor det religiøse og profane fremstilledes med en så grænseoverskridende effekt, at samtiden $\mathrm{i}$ hvert fald var enige om éen ting: Noget lignende havde man aldrig før set eller kunnet forestille sig blive fremført på en teaterscene.

Med sin stemningsfulde dekoration, der forestiller en måneskinsbelyst klosterruin, og den dramatiske pantomimiske-koreografiske handling, som fremstiller en gruppe spøgelsesagtige hvidklædte nonner, der stiger op af deres grave for at deltage i et natligt bakkanal, blev denne ballet på mange måder forløberen for alle de senere såkaldte "hvide balletter" (eller ballets blancs), der kendetegnede hele den balletromantiske periode og endnu kan opleves den dag i dag med et værk som La Sylphide (uropført kun tre måneder senere i Paris og genopsat af August Bournonville i Køben- 


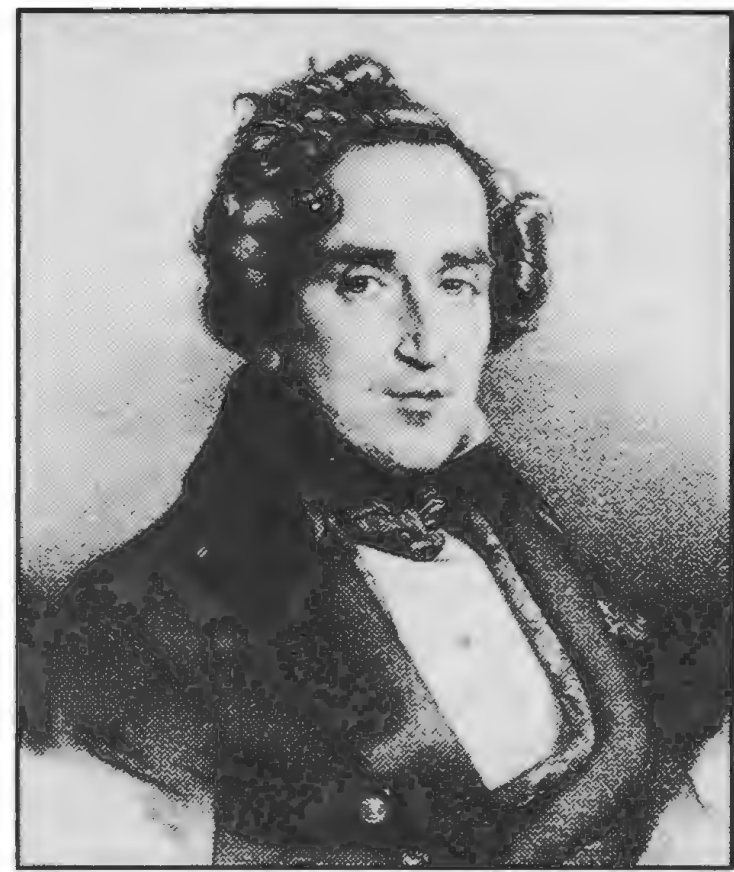

Komponisten Giacomo Meyerbeer (privateje).

havn i nydigtet form i 1836) samt balletten Giselle (uropført i Paris i 1841).

Koreografien til Meyerbeers og Taglionis ballet afslører også, hvordan de erotiske og dæmoniske drifter hos mennesket var genstand for datidens store interesse. Meget er i tidens løb derfor blevet skrevet om dette berømte balletoptrin og dets betydning i ballet- og musikhistorien, hvorimod kun ganske få ballet- og musikhistorikere har vovet sig ind på en mere eksakt indholdsanalyse af selve det dansede værk.

Grunden til forskernes tøven overfor en analytisk mere indgående behandling af denne epokegørende ballet skal nok primært søges i den kendsgerning, at vi indtil i dag kun har vidst meget lidt om koreografien og selve den dansestil, som denne ballet konkret udførtes med. Dansen er jo som bekendt den vel nok mest flygtige af alle scenens kunstarter, og fortiden har indenfor dette kunstneriske felt derfor kun efterladt meget sparsomme kilder til belysning af datidens koreografiske mesterværker.

I sin bog The Romantic Ballet in Paris har den engelske ballethistoriker Ivor Guest genskabt hele tilblivelseshistorien omkring Meyerbeers og Taglionis ballet. Fra dette værk kan vi blandt andet lære om hvordan ballettens korpsafdeling blev koreograferet og iscenesat på $i$ alt seks uger, hvorimod selve solo-ballerinaens store parti blev skabt på mindre end kun 3 uger.

En anden og meget vigtig kilde til studiet af tilblivelsen og indholdet af denne ballet er Meyerbeers egne autograf-skitser til musikken, som i dag befinder sig på Pariseroperaens bibliotek. I dette manuskript har komponisten

Koreografen Filippo Taglioni (Museo Teatrale alla Scala, Milano).

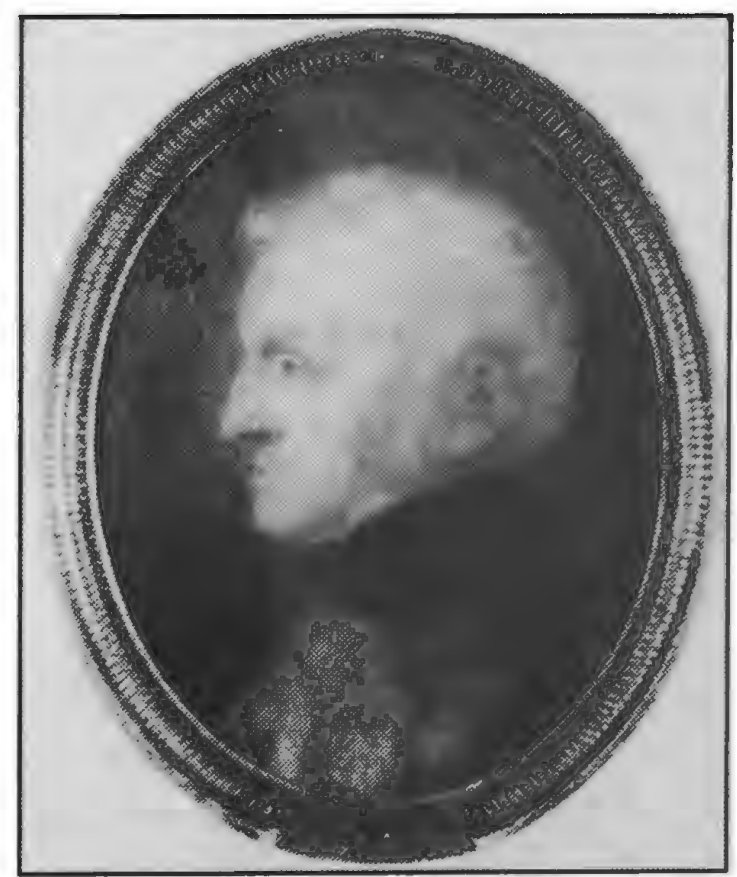




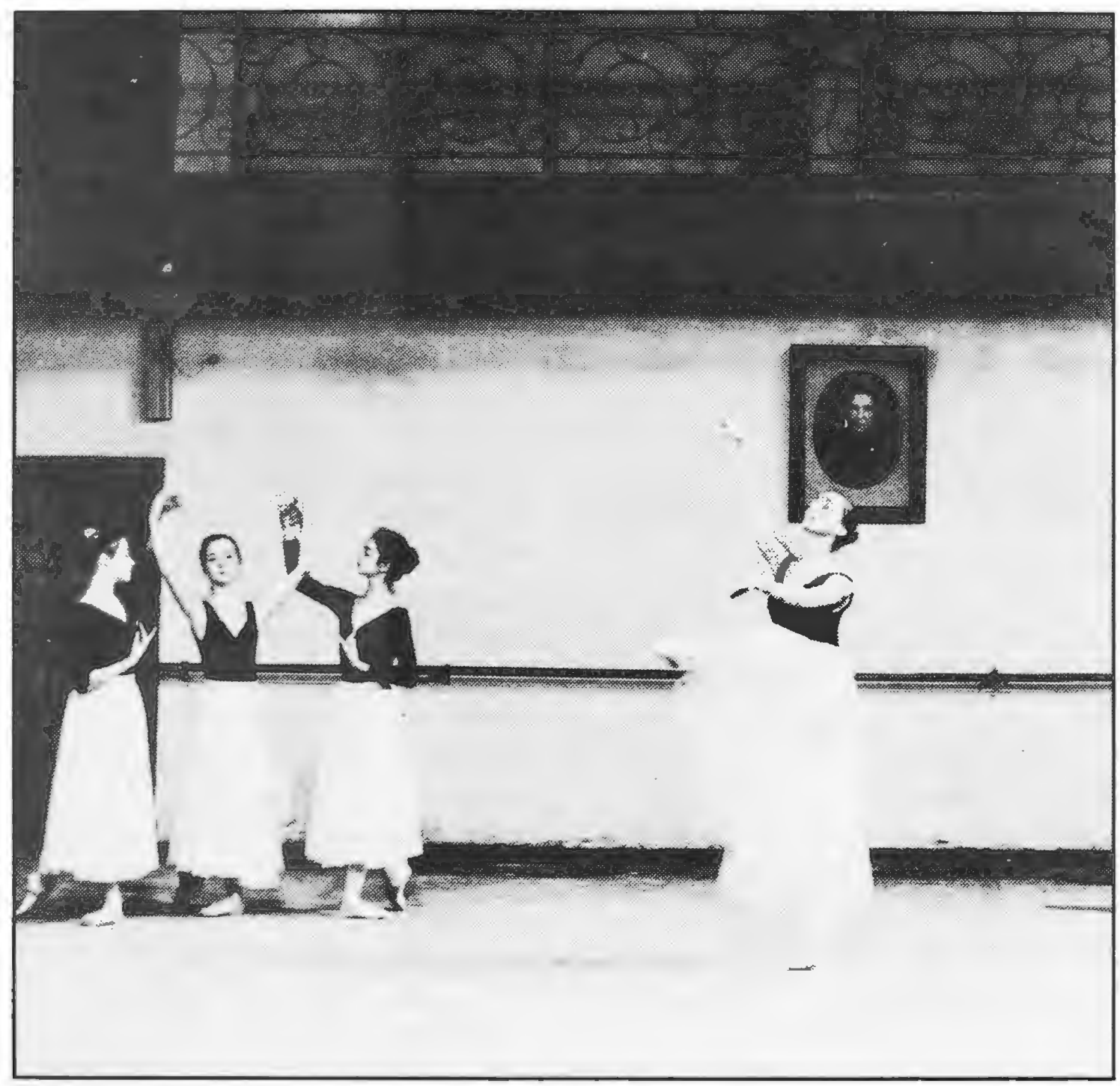

Lena Kozjakova og studerende ved Vaganova Balletakademiet i Skt. Petersborg under en prove på Knud Arne Jürgensens rekonstruktion af balletten i Meyerbeers opera Robert le Diable (Oktober 1986).

indsat en lang række iscenesættelsesnotater, der omhandler hans ønsker for hvorledes koreografien burde udformes og hvad den helt konkret skulle fremstille i trin og pantomime.

Fra koreografen Filippo Taglionis dagbøger (som i dag også findes bevaret på Pariseroperaens bibliotek) ${ }^{2}$ kan vi desuden følge hele indstuderingsforløbet på nærmeste hold. Meyerbeers og Taglionis noter vidner således om et overordentlig tæt kunstnerisk samarbejde mellem komponist og koreograf, hvilket dengang måske ikke ligefrem var det mest almindelige indenfor det balletmusikalske område.

Den store følsomhed, som Meyerbeer afslører i disse noter overfor hans koreografs ønsker og arbejde, repræsenterer derfor nok også en af hoved- 
grundene til at netop balletten i Robert le Diable blev af så afgørende betydning for hele balletkunstens videre historiske forløb. Kun uhyre sjældent fik et balletdivertissement $\mathrm{i}$ en opera så stor opmærksomhed fra komponistens side, som det var tilfældet med Meyerbeers opera. Det overordentlige fine samspil mellem musikken og koreografien til dette værk afspejler sig da også klart i komponisten Hector Berlioz's uhyre interessante anmeldelse af værket i det toneangivende Parisiske dagblad Journal des Debats den 16. december 1831:

“...Le décor change et représente le cloître aux voûtes sombres et profondes, le caveau sépulchral des nonnes de SainteRosalie. La décoration musical change aussi: les trombones et l'ophicléide sonnent à l'unisson; leur voix solennelle et funèbre annonce l'arrivée de Bertam; un concert de violoncelles et de bassons unit son harmonie triste et sévère au récitatif obligé chanté par cet esprit de ténèbres. Cette invocation est de la plus grande beauté:

Pour une heure, quittez votre lit funéraire;

\section{Nonnes, relevez-vous!}

Et les nonnes, obéissant au pouvoir discrétionnaire de leur président, se relèvent et reprennent peu à peu une existence éphémère, et, comme le diable ne leur rend pas la faculté de parler, dans la crainte qu'il ne leur prît fantasie de nous raconter leurs vies, elles restent silencieuses et laissent à l'orchestre le soin de peindre leurs sentimens, de donner une seconde interprétation à leurs gestes en s'unissant à leur pantomime expresssive. Le chant instrumental frappe seul l'oreille pendant cette longue et belle scène, et son charme, ses images pittoresques, ses couleurs variées, ses détails pleins d'esprit et de vigueur de sentiment font sur l'âme une sensation profonde. Le prestige de la musique vient accrôttre dans une progression immense le prestige de la décoration et les séductions de la pantomime.

Les nonnes se relèvent, et les bassons seuls font entendre un chant dont la mélodie ascendante suit le mouvement des statues qui décrivent lentement un quart de cercle pour arriver à la position perpendiculaire. Le pizzicato des contrebasses, les trombones en sourdine suivent la route mystérieuse que les bassons ont tracée. L'orchestre s'anime peu à peu par l'entrée succesive de tous les instrumens; le ton mineur, qui a regné pendant tout le temps de cette opération galvanique et fantastique, est remplacé tout à coup par un ensemble éclatante en un majeur, et le bécarre posé sur le mi signale aux moins intelligens la vitalité de ces dames, et nous avertit qu'elles sont de nouveau des fermmes du monde.

Les nonnes savent qu'elles n'ont que cinquante-neuf minutes de congé; elles n'en sont pas plus tristes, et s'empressent de profiter du bon temps que messire Lucifer veut bien leur accorder. Ces joyeuses sours commencent par ôter leurs voiles et leurs longues robes, elles ne gardent qu'une légère tunique. Chacune court à son cellier y prendre coupes et flacons; ce cellier, c'est leur tombeau; le vin doit être frais. Elles avalent à longs traits le vin de Chypre ou de Val-de-Pegnas pour se rafraîchir la bouche, où les araignées ont peut-être tissu 
des toiles: cela donne du caur à la danse, et les voilà pirouettant comme des toupies, dansant des rondes et la farandoule, se démenant comme des possédés. Cette galope, sur un six-huit en ré mineur, avec acompagnement de triangle, et dont l'effet est entraînant, et toutes ces joyeusetés se passent nécessairement dans la nuit du sépulcre..."

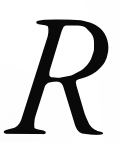

obert le Diable blev omgående datidens største operahit og kom på rekordtid på scenerne overalt i Europa; operaen opnåede i Paris alene mere end 470 opførelser i Meyerbeers egen levetid.

Ballettens hovedparti blev dog kun udført af Marie Taglioni ialt seks gange, hvorefter partiet blev overtaget af den franske danserinde Louise Fitzjames. Hun udførte det ved ialt 232 på hinanden følgende opførelser - ikke så lidt af en bedrift i ballethistorien.

Årsagen til at Marie Taglioni tilsyneladende selv bad sig fri for partiet på et så tidligt tidspunkt af operaens opførelseshistorie skal nok mest findes i den kendsgerning, at hun på netop samme tid var midt $i$ at kreére den ballet, der på det nærmeste skulle blive et synonym for hendes navn, La Sylphide. Det er dog også en mulighed, at det som Taglioni måske mest manglede i sin egen kunstnerpersonlighed var den særegne form for djævelsk-erotisk karisma, som netop hovedpartiet i Meyerbeers ballet fordrede. Taglioni har derfor måske nok følt at den udprægede "ondsindede" hovedrolle i Meyerbeers ballet i såvel udtryk som indhold lå for langt væk fra den mere "godsindede" rolle, som titel-

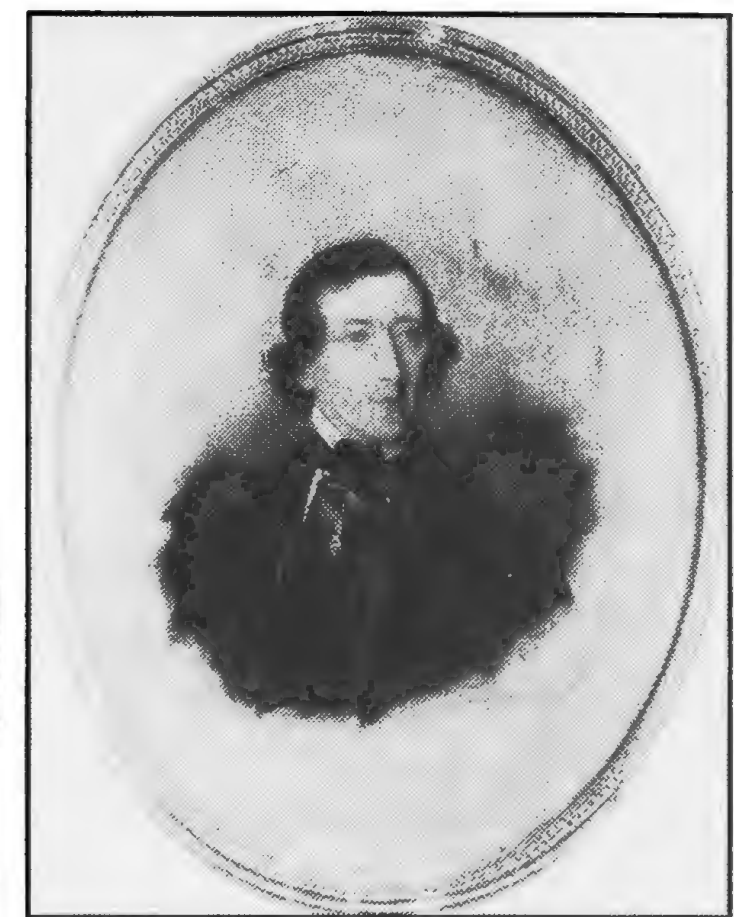

August Bournonville (1842), malet af Emilius Barentzsen (privateje).

partiet i La Sylphide repræsenterede, og som netop optog alle hendes kræfter i denne periode.

\section{Under alle omstændigheder} synes hendes efterfølger i partiet, Louise Fitzjames, at have besiddet præcis den form for erotisk karisma, som balletten i Robert le Diable krævede, eftersom denne danserinde på det nærmeste opnåede at få monopol på rollen i Paris i gennem de mange følgende år.

T foråret 1841 oplevede vor egen balletmester, August Bournonville, denne franske ballerina i hovedrollen i Meyerbeers ballet i Paris, ligesom han (ifølge sine rejsedagbøger) igen så hende optræde i balletten under et senere besøg i Paris i 1847.

Hjemme i København ned- 


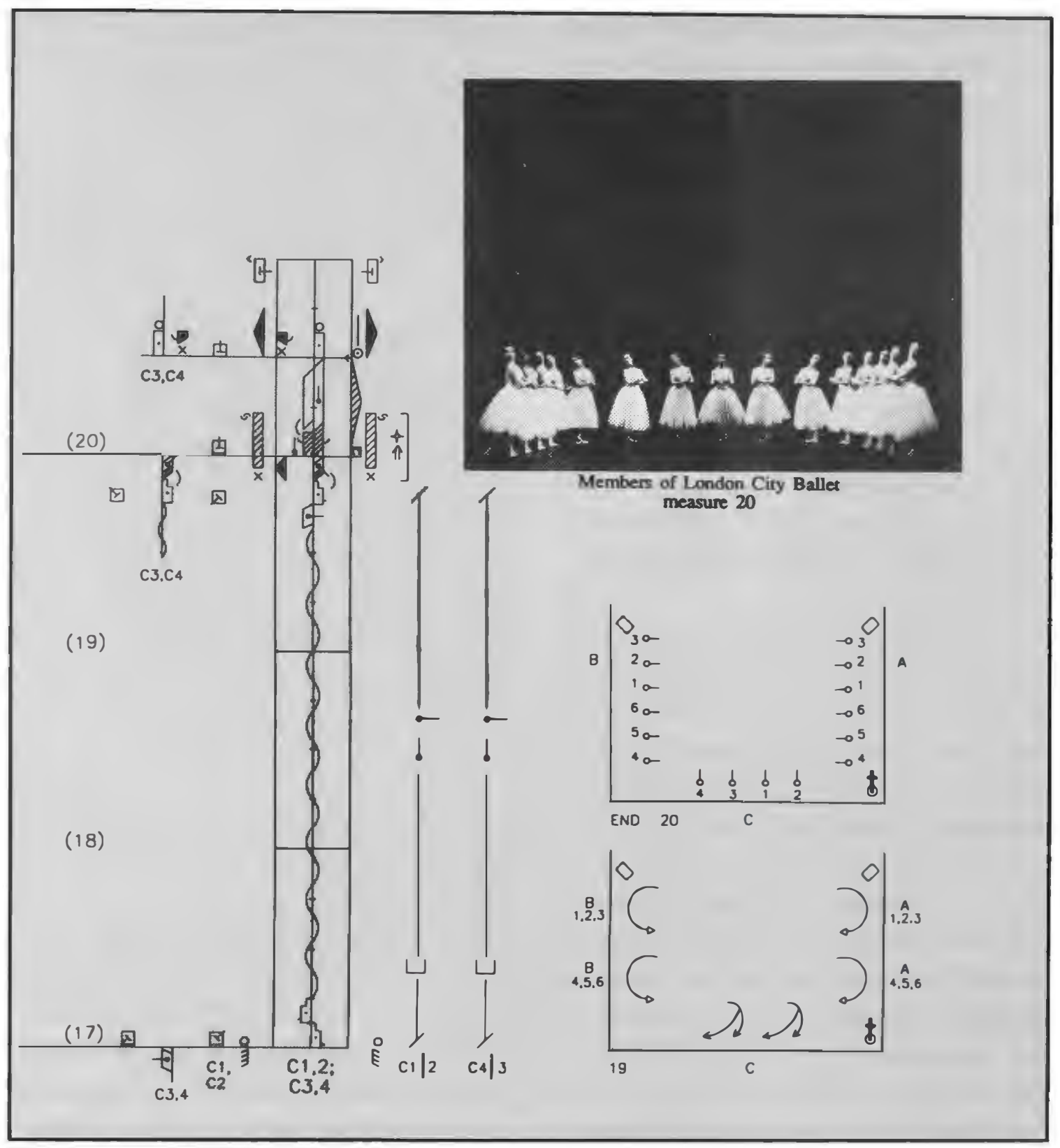

2 eksempler (her nedskrevet $i$ notationssystemet Labanotation) med Knud Arne Jürgensens rekonstruktion af August Bournonvilles optegnelser af koreografien til 3. akt af Giacomo Meyerbeers opera Robert le Diable.

skrev Bournonville Taglionis koreografi efter Fitzjames' udførelse i et repetitørparti til Meyerbeers opera. Disse optegnelser blev nedfældet og senere benyttet af Bournonville til hans egen første iscenesættelse af Robert le Diable i Kø- benhavn d. 18. januar 1848 (i Danmark blev operaen opført på dansk med titlen Robert af Normandiet). Senere supplerede Bournonville disse optegnelser med andre og mere fyldestgørende notater, der blev benyttet til hans opsæetning af 


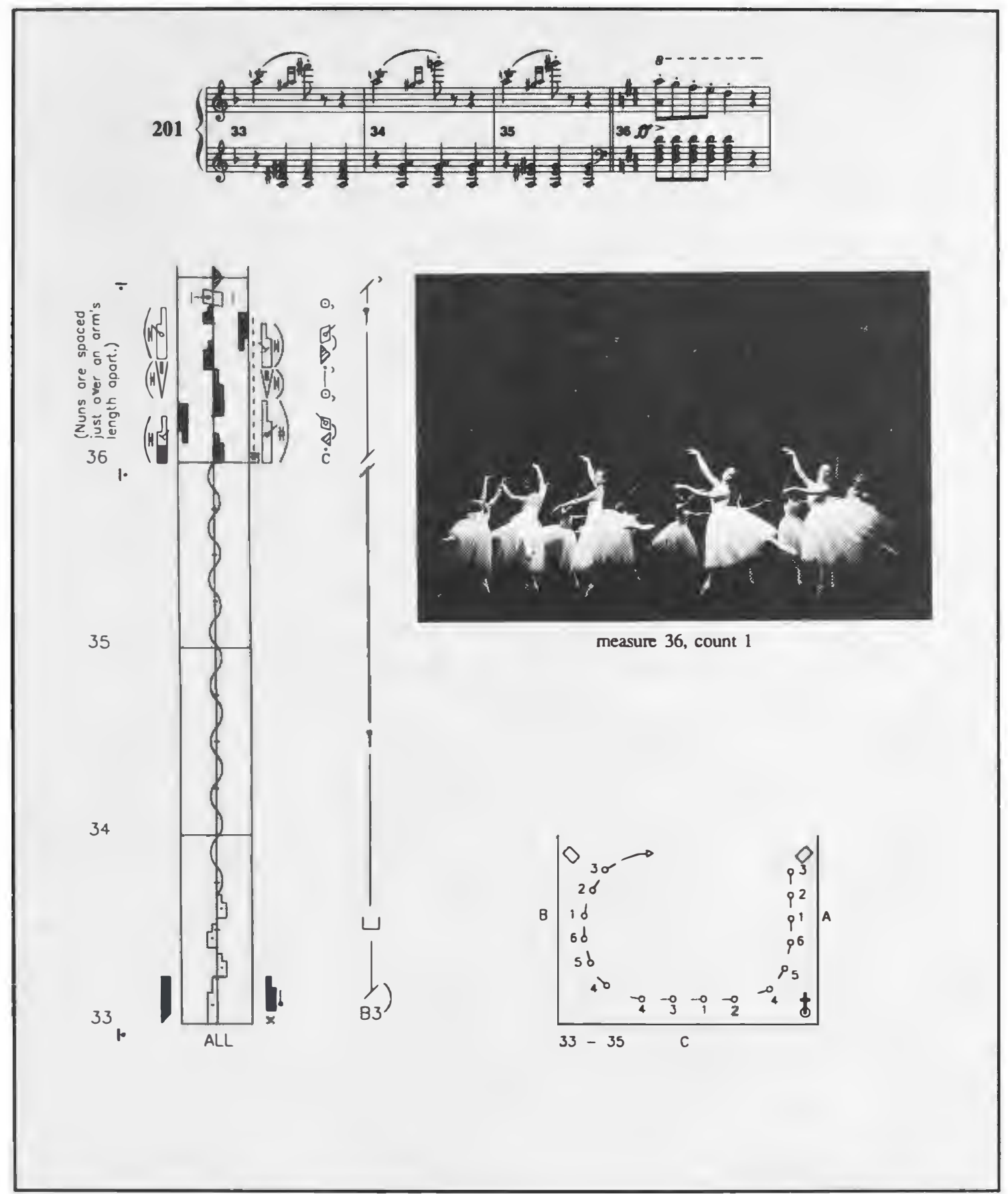

Meyerbeers opera på Wiens Kärnthnerhavn den 19. januar 1873, hvor hovedthor Theater den 23. juli 1855, nu med hovedpartiet udført af hans egen elev, solodanserinden Juliette Price.

Endelig nedskrev Bournonville hele balletten påny i forbindelse med sin sidste opsætning af operaen i Købenpartiet nu blev udført af den svenskfødte danserinde Marie Westberg. Alle disse optegnelser samt nogle yderligere koreografiske beskrivelser nedskrevet af Bournonvilles efterfølger, Emil Hansen, har jeg for nylig 


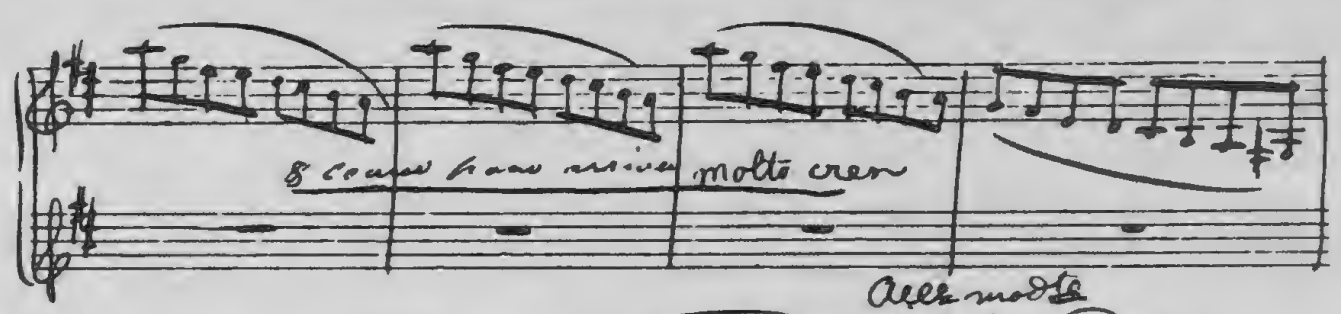

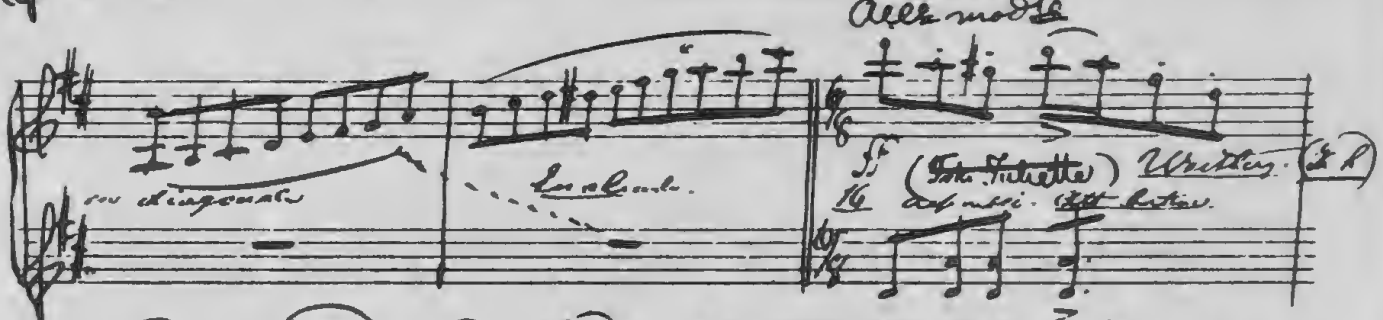

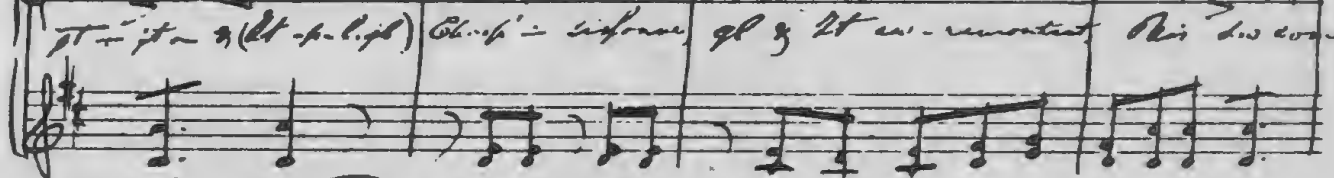

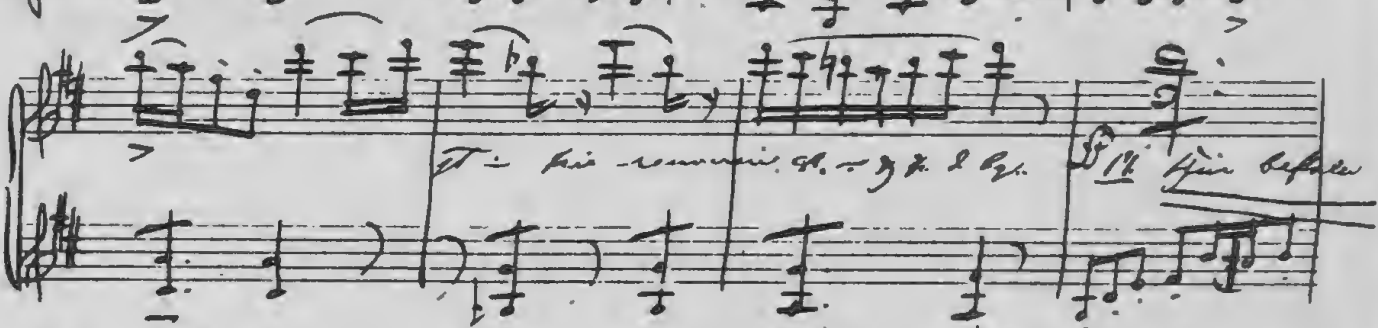

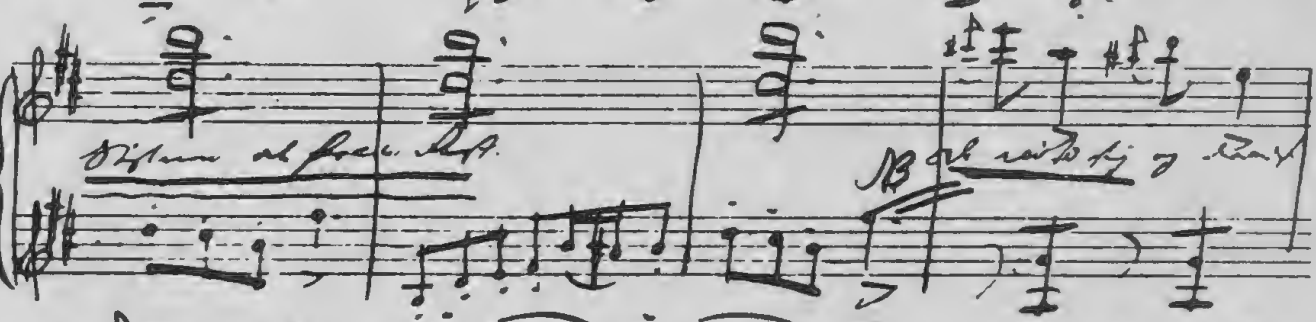
14 14 It

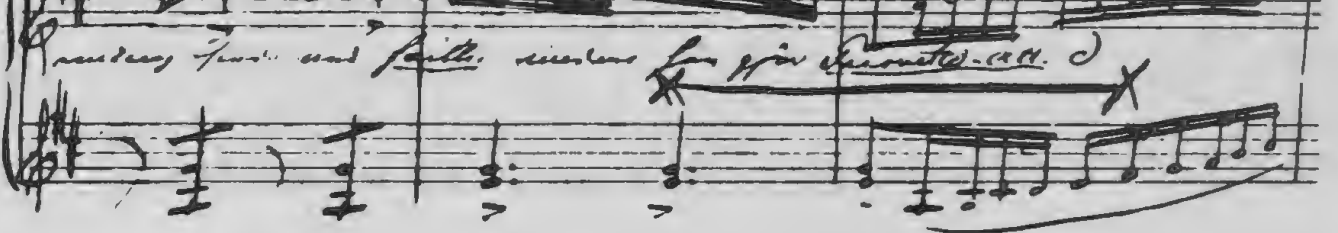

Eksempel på August Bournonvilles nedskrivning afkoreografien til balletten i 3. akt af Robert le Diable. 
genfundet i Det Kongelige Biblioteks samlinger. ${ }^{3}$ Tilsammen har de kunnet danne grundlag for en komplet koreografisk rekonstruktion af denne vigtige historiske ballet, og materialet foreligger derfor nu i bogform med et tilhørende koreografisk notationspartitur (nedskrevet i den såkaldte Labanotation af Dr. Ann Hutchinson Guest) og udgivet på det internationale forlag for de udøvende kunstarter, Gordon and Breach Publishers, i London. 4

Noget af det som umiddelbart falder en mest i øjnene, når man sammenligner Bournonvilles og hans efterfølger Emil Hansens optegnelser af denne ballet, er deres påaldende ensartethed både hvad angår de enkelte trinbeskrivelser og de mere generelle koreografiske diagrammer. Generelt synes det her klart som om, at denne ballet blev udført i en omtrent uændret form i København gennem mere end halvtreds år. De danske kilder til balletten i Meyerbeers opera repræsenterer derfor et enestående eksempel på, hvordan vi med Bournonvilles koreografiske optegnelser i Danmark har bevaret nogle af den romantiske ballets mest berømte balletdivertissementer og solodanse, og som $\mathrm{i}$ dag gør det muligt på en sjælden levende og håndgribelig måde at studere hele det eksakte koreografisk-æstetiske trinsprog, som fulgte med den romantiske ballets blomstring.

Selv om Det Kongelige Teater i forrige århundrede kun var af sekundær betydning som kunstcentrum, blev balletten dér ledet af en kunstner med endog meget dybe rødder i den franske balletkultur. Bournonvilles koreografiske notater til hans egne værker og de fremmede balletter, han opsatte gennem sine næsten halvtreds år som balletmester $\mathrm{i}$ København, repræsenterer derfor en enestående mulighed for et indblik i selve kernen - eller hjertekammeret - af den europæiske romantiske ballet.

Med deres koreografiske udfordring og store musikalske kvaliteter er disse forlængst glemte, men nedskrevne og dermed stadig bevarede balletter desuden en potentiel inspirationskilde for vore dages kunstnere, iscenesættere og publikum, for hvem Bournonvilles kunst forlængst er blevet en kær ejendom.

Efter at have rekonstrueret og genopsat Bournonvilles nedskrevne koreografi til balletten i Robert le Diable ved tre lejligheder $i$ udlandet (London, Skt. Petersborg og Napoli), er jeg personligt således blevet overbevist om denne ballets overordentlige fine musikalske og koreografiske kvaliteter. Det er måske netop denne ballets sjældne blanding af meget krævende danseteknik og kunstnerisk åndfuldhed, som er en af hovedårsagerne til at dette værk fascinerede datidens publikum så meget og dermed fik så afgørende betydning for hele balletkunstens videre kunstneriske udvikling.

Når Berlins Staatsoper under Daniel Barenboims musikalske ledelse i år 2000 genopfører Meyerbeers Robert le Diable $\mathrm{i}$ en ny og kritisk revideret udgave, skal det blive spændende at se, om man til balletten i 3. akt vælger at genopsætte August Bournonvilles nu genfundne og genskabte version af dette historiske epokegørende værk. 
Noter

1 Jvfr. Erik Aschengreen: Farlige Sylfider (København, 1975, s.27) og Gyldendals Musikhistorie, bind 2, s. 218-129, 1983.

2 Bibliothèque-Musée de l'Opéra de Paris, signatur: Res. A. 500 a 2 (p).

3 Bibliothèque-Musée de l'Opéra de Paris, signatur: Fonds Taglioni R 25.

4 De 3 repetitørpartier, som indeholder Bournonvilles og Emil Hansens koreografiske optegnelser til balletten i Robert af Normandiet (Robert le Diable) befinder sig i dag i Det Kongelige Biblioteks Musikafdeling under opstillingssignaturerne: MA ms 3065 (KTA 303 (1)), MA ms 2920 (1) (KTA 303 (2), og MA ms 3066 (KTA 303 (3).

5 Jürgensen, Knud Arne og Guest, Ann Hutchinson : Robert le Diable - The Ballet of the Nuns. Gordon and Breach Publishers, Language of Dance Series, No. 7 , London, 1997.
Litteratur:

Aschengreen, Erik: Farlige Sylfider, Studier i den romantiske ballet i Frankrig og Danmark (København, Selskabet for Dansk Teaterhistorie, 1975).

Guest, Ivor, The Romantic Ballet in Paris (2nd revised edition, London, Dance Books, 1980).

Guest, Ann Hutchinson: $A$ Trip to the Nunnery in Dancing Times (London, March 1985, s. 498-499).

Jürgensen, Knud Arne og Guest, Ann Hutchinson: The Bournonville Heritage - A Choreographic Record 1829-1875, I-II (London, Dance Books, 1990)

Jürgensen, Knud Arne: The Reconstruction of the Original Choreography of the "Ballet des nonnes" from "Robert le diable" (i Meyerbeer und der Tanz, Thurnau, Forschungsinstitut für Musiktheater, 1995).

Jürgensen, Knud Arne: Is Verdis ballet for Macbeth a "Replay" of that in Meyerbeer's Robert le Diable (i Meyerbeer un der Tanz, Kongre $\beta$-bericht, Thurnau, Forschungsinstitut für Musiktheater, 1998). 